\title{
Indigenous-inclusive citizenship: the city and social housing in Canada, New Zealand, and Australia
}

\author{
Ryan Walker \\ Department of Geography and Planning, University of Saskatchewan, 117 Science Place, \\ Saskatoon, SK S7N 5C8, Canada; e-mail: ryan.walker@usask.ca
}

Manuhuia Barcham

Centre for Aboriginal Economic Policy Research, The Australian National University, Canberra, ACT, 0200, Australia; e-mail: mbarcham@synexe.com

Received 12 October 2008; in revised form 7 January 2009

\begin{abstract}
Indigenous peoples in Canada, New Zealand, and Australia are highly urbanised. In spite of this, urban Indigenous communities have a difficult time giving effect to self-determining autonomy in comparison with their rural, remote, and reserve counterpart communities. The place of authentic Indigeneity in the public perception has remained outside of urban areas. All three countries have had social housing initiatives that aim to even out life-chances among citizens. How Indigeneity features in the housing sector varies from country to country. Through an examination of social housing developments from the 1930s to the present, we develop knowledge of how the place of authentic Indigeneity has changed over time and has been linked to the creation of Indigenous-inclusive citizenship in the city. While the Canadian experience continues to pair self-government with common social housing goals, New Zealand never really linked self-government with common social citizenship in the housing sector; Australia did for a time, but it is regressing quickly.
\end{abstract}

Indigenous peoples in Canada, New Zealand, and Australia are highly urbanised. In Canada, roughly 54\% live in urban centres (Statistics Canada, 2008). In New Zealand and Australia the figures are $83 \%$ and $74 \%$, respectively (Statistics New Zealand, 2002; Australian Bureau of Statistics, 2002). In spite of these numbers, urban Indigenous communities have a difficult time giving effect to the principle of self-determination in urban policy - in absolute terms, but also relatively speaking in comparison with counterpart communities in rural and remote areas (Andersen and Denis, 2003; Barcham, 2000). We use developments in urban social housing in Canada, New Zealand, and Australia as a means for engaging with urban Indigeneity and understanding how the 'hegemony of exclusion' (Howitt, 2001) that keeps it outside of the shared urban experience can be overcome. This is an important piece in the overall project of urbanists worldwide to understand and facilitate the decolonisation of our cities, overcome a lingering fear of the 'other', and embrace in practical ways a 'politics of difference' (Sandercock, 2003).

All three countries have a history of social housing initiatives that aimed to even out life-chances for all citizens by ensuring access to adequate and affordable housing. Within those initiatives, in all three countries, are a set of social housing programmes that were created specifically for Indigenous peoples. The extent to which these programmes supported urbanisation trends among Indigenous peoples varies. While each of the three countries has its own body of scholarship on Aboriginal (urban) housing (eg, Read, 2000; Waldegrave et al, 2006; Walker, 2008) ours is the first international comparative work across the three countries. We use an historic comparative examination of Indigenous social housing programmes, from the 1930s to the present, in order to understand how common social citizenship, Indigenous-inclusive citizenship, and the perceived legitimate place for authentic Indigenous cultures have intersected. We argue that the links between Indigenous-inclusive citizenship and common social 
citizenship in the urban housing sectors of the three countries are contingent, and that self-government does not in itself assure steady progress toward "a post-colonial alternative for living together differently without drifting apart" (Maaka and Fleras, 2005, page 300$)$.

In the next section we explain our theoretical framework, providing the reader with our understanding of Indigenous citizenship and the place of Indigenous cultures in urban areas. The approaches taken in each of the three countries to urban Indigenous social housing are then examined through our theoretical lens. We end by discerning lessons from our three country histories in a comparative perspective.

\section{Placing Indigenous citizenship}

\section{Universal citizenship $\leftrightarrow$ Indigenous inclusive citizenship}

The debate around how the inherent right of Indigenous self-determination factors into the common citizenship of a nation-state is vigorous and ongoing (eg, Alfred, 2005; Cairns, 2000; Fleras and Spoonley, 1999; Peterson and Sanders, 1998; Sissons, 2005; Wood, 2003). It tends to be anchored on one end by a notion of universal citizenship which centres on the common identity all share within a nation-state framework, the entitlements and responsibilities this confers, and shared practices it reproduces. This model of citizenship has serious shortcomings, understood by academics (eg, Kymlicka, 2001), but nonetheless persistent among white Settler publics, because it fails to account for the fact that Indigenous societies were determining their own affairs prior to resettlement and never alienated their collective rights to continue doing so, although alongside white Settler societies according to treaties and natural law. This is made more complicated given that white Settler nations have had to reimagine the meaning of mainstream culture in a way that is more multicultural over past decades, something that has created a counterproductive tendency to elide Indigeneity with multiculturalism.

The very concept of citizenship in liberal democratic countries has been critiqued for some of its incompatibilities with the aspirations of Indigenous peoples (eg, Alfred, 1999; Mercer, 2003; Sissons, 2005). The basic group rights of Indigenous political communities to self-determination are displaced by the precedence of individual rights and universal applicability (Mercer, 2003). The sanctity of individual rights - so central to the state-society (citizenship) compact - is notably Eurocentric (Alfred, 1999; Sissons, 2005). It diminishes the importance placed by Indigenous peoples on the sustainable reproduction of relationships to community and kinship, land, culture, and spirituality (Alfred, 2005). Liberal democratic notions of citizenship can seem incomplete in comparison and, in their pervasive and uncontested practice, hegemonic.

The other anchor in this debate is the notion of common national citizenship as a model that includes Indigenous self-determination as a fundamental piece of statesociety relations. Roger Maaka and Augie Fleras (2005) have conceptualised the dichotomy we have just described as universal versus Indigenous-inclusive citizenship. Recognising self-determination, with meaningful consequences in statute, policy, and practice, is a foundation of Indigenous-inclusive citizenship. This is a significant theoretical departure from the idea that 'one size fits all', or 'one size should fit all', that characterises universal citizenship. It is an even more significant, and indeed a very challenging, departure from current practice in urban policy, where embedding selfdetermination into acceptable governance parlance at the local level is not yet common (Walker, 2006).

Indigenous scholars are consistent in their articulation that the (collective) right of self-determination is central to Indigenous citizenship within the nation-state context 
and that it comprises cultural, political, economic, social, and legal content (Durie, 2003; Green, 2005; Maaka and Fleras, 2005; Maynard, 2007).

New Zealand is constitutionally a bicultural society. The Treaty of Waitangi (1840) is one of the country's founding documents, articulating the legal basis for the relationship between Pākehā (European) and Māori. In practice New Zealand is more advanced than Australia or Canada in giving effect to the principle of self-determination, specifically with regard to treaty settlements and transfers of assets back to Māori tribal groups. But in other areas, such as the design and delivery of elements of common citizenship which include some measure of Indigenous autonomy in design and delivery, such as social welfare policy, like housing, it is less advanced than the other two countries.

In Canada, self-determination, when rearticulated with new vigour beginning in 1969 (Cardinal, 1969), took little time to become synonymous with (self-)government structures, typically associated with land-bases, elections, and so forth, most easily reconcilable with mainstream Canadian views of how peoples define and govern themselves (Andersen and Denis, 2003; Green, 1997). In Australia, self-determination had a vigorous start in the early 1970s, and has been moderated through replacement by the principle of self-management over time (Mulgan, 1998). Self-government and self-management are not synonymous with self-determination, but are the compromises that have been made operational in welfare and service sectors like housing, health, and education. The concepts of self-government and self-management amount, in policy terms, to administrative arrangements with government, where Aboriginal communities or organisations will implement government programmes with perhaps some flexibility to do things in culturally appropriate ways.

There are different ways of viewing self-government as it relates to the advancement of self-determination and, ultimately, Indigenous-inclusive citizenship. Taiaiake Alfred, for example, likens self-government reforms to being handed the 'scraps of history', arguing that:

"These surface reforms are being offered because they are useless to our survival as Onkwehonwe. This is not a coincidence, nor is it a result of our goals being obsolete. Self-government and economic development are being offered precisely because they are useless to us in the struggle to survive as peoples and so are no threat to the Settlers and, specifically, the interests of the people who control the Settler state" (Alfred, 2005, page 37, original emphasis).

Indigenous self-government can amount to Indigenous 'state-determination' (Maaka and Fleras, 2005) if simply a tightly circumscribed transfer of administrative authority for a state-derived programme, with little real autonomy exercised by Indigenous communities in priority-setting, design, and delivery based on community values and worldviews. Self-government in a policy sector, for example, can effectively undermine the implementation of self-determination, if it amounts to a simple administrative offload of a state-formulated policy field to an Indigenous organisation(s). There are examples of policy fields in all three countries where in the recent past Indigenous organisations or communities have assumed 'self-government/management' over a set of Eurocentric policies and programmes, where Indigenous people administering the programmes become the oppressors by proxy of their own communities (Walker et al, forthcoming). There are also concerns that the goals of neoliberal state divestment from a variety of policy sectors fundamental to state-society relations too easily coincide with movements toward Indigenous self-government (Durie, 1998), replacing state responsibility for investment in common social citizenship with Indigenous accountability, although without a sufficient transfer of jurisdiction or sustainable resources. 
Yet self-government can also allow for marginal improvements to the implementation of common citizenship, such as in social sectors like housing, health, and education, basic standards of which most would agree are entitlements of all citizens (within and outside of treaties) (Royal Commission on Aboriginal Peoples, 1996). The design and delivery of policy and programmes in these sectors can be improved through some adherence to the principles of Indigenous-inclusive citizenship, even if only a circumscribed (eg, by Settler government statute) application of self-determining autonomy (Minore and Katt, 2007). The relationship between the normative principle of Indigenous-inclusive citizenship (Maaka and Fleras, 2005) - where self-determination is a fundamental component of common national citizenship in a (not-yet-realised) postcolonial Settler state-and the more commonly implemented forms of Indigenous self-government is contested and contingent. In this paper we explore this contingency.

\section{Rural/remote/reserve $\leftrightarrow$ urban}

If Indigenous-inclusive citizenship embodying the principle of self-determination is challenging in the universe of political discourse at the national level, it is even more so at the urban scale where mainstream society maintains a particular view of where the legitimate territorial basis for authentic Indigeneity lies. There have for several decades been cohesive and identifiable urban Indigenous communities in cities across all three countries (Morgan, 2006; Sissons, 2005). Their legitimacy as political communities that would seek to reproduce Indigeneity in the city and exercise self-determining autonomy in urban affairs has been challenged by non-Indigenous citizens, governments, and - where power struggles over scarce resources occur-by other Indigenous communities linked to discrete rural, remote, or reserve land-bases (Andersen and Denis, 2003; Barcham, 2000).

Evelyn Peters (1996, page 60) explains that "[t]he social construction of aboriginal peoples incorporates a sense of where they 'belong' as peoples with vital and authentic cultures. In European thought, aboriginal culture is incompatible with urban life." Writing on Indigeneity in metropolitan Australia, Kay Anderson (2000) examines the distinctions in public consciousness between 'savagery' and 'civility', and how metropolitan urban life coincides with (white) 'civilized' culture and is incompatible with (black) Indigenous 'savage or natural' culture which belongs somewhere 'out there' in discrete rural and remote communities. Indigenous peoples moving to urban centres, in both Anderson's and Peters' accounts, are supposed by Settler societies to adopt mainstream western values in the city. The hegemony of universal citizenship principles are strongest in the city, where many cultures coexist and the dominant norms of Settler society are perceived in the mainstream as culturally neutral. Indigenous culture, as far as it is perceived to exist at all within urban Settler society, has its own bounded spaces-discrete rural, remote, and reserve communities - to reproduce itself and maintain its vitality.

History shows that authentic Indigeneity is not discarded at the city limits. One example is inner Sydney, Australia, where Indigenous people from many parts of the country formed a cohesive political community, from which the national movement for self-determination and land-rights on traditional territories got much traction from a land-rights march to Parliament starting there in 1972 (Morgan, 2006). In Sydney, Indigenous households would move from 'better' housing in newer suburban neighbourhoods to live in proximity to this large urban (multi-Aboriginal-cultural) Indigenous community in the inner city, and the numerous urban institutions that grew out of it (eg, health, legal, housing, cultural, arts). In Canada the preferred neighbourhoods for living and raising children for a group of Indigenous lone-parent women in Winnipeg were in an area of town which is lowest on most socioeconomic indicators, but has 
a high concentration of Indigenous people and institutions (Mochama, 2001; Skelton, 2002).

George Morgan (2006) explains how, instead of undergoing a depletion of their Indigeneity in the move from rural and remote Australia to cities, Aboriginal peoples recombined aspects of traditional life with the modern urban experience. Racism, social exclusion, and disadvantage have had an enormous impact on the constitution and reproduction of contemporary Indigenous urban communities, as have traditional community values (Sissons, 2005). Morgan (2006, page 154) notes that the urban articulations of Indigeneity "do not represent a breach with the past or a point of disjunction. They continue to be the forms that serve to constitute Aboriginal solidarity and they are no less Indigenous culture than are corroborees, dreaming stories and body paint."

Moving from the social to the political, although virtually inseparable, Chris Andersen and Claude Denis (2003, page 376) write:

"[s]ince the early 1970s in Canada, Aboriginal political resurgence has meant that certain kinds of Aboriginal political claims have been legitimized. At the same time, other such claims - or potential claims - have not gained the same visibility. Specifically, the needs and aspirations of urban Aboriginals have remained marginal, while many government negotiations with Aboriginals on (or linked to) a recognized land base have moved ahead."

In New Zealand, Manuhuia Barcham (1998; 2000) has challenged the 'iwi-isation' (iwi means tribe) of Māori claims to political identity and resource allocation in the past few decades which have frozen legitimate iwi structures and land-bases at their configuration when the Treaty of Waitangi was signed in 1840. This is problematic because iwi structures (prior to being frozen in time) were dynamic and strategic alliances, shifting over time. There is no essential reason why urban Māori political communities that have created urban space for themselves and perpetuated norms, practices, and institutions over the past few decades should be seen as illegitimate or inauthentic forms of Māori (iwi-tribal) political community (Maaka, 1994). Yet they struggle continuously for that recognition, much like urban Indigenous communities in Canada. Vital and dynamic Indigenous cultures will-like non-Indigenous cultures subject to pressures of modernism - adapt to changing environments. There are few, if any, political communities in the Western world that have not transformed dramatically since the $1800 \mathrm{~s}$.

\section{Housing as a foundation of common (social) citizenship}

Examining changes over time in state-driven social housing, a welfare sector used to build common social citizenship in all three countries, is useful for exploring the contested and contingent paths of universal-Indigenous-inclusive citizenship and where the place of authentic Indigeneity is situated in mainstream public consciousness. While state redistribution through the social housing sector has changed a great deal over the time period we examine (Darcy, 1999; Thorns, 2000; Wolfe, 1998), our focus is less on those changes, in general, than it is on the ways in which countries have proceeded with respect to Indigenous-inclusive citizenship in urban areas.

Adequate and affordable housing is central to quality of life in cities (Hulchanski, 2002). When state responsibility to resource common social standards of citizenship is upheld, self-government by Indigenous communities or organisations in the design and implementation of housing programmes has tended to improve outcomes in urban areas, compared with mainstream social housing, because of the closer adherence to culturally linked conceptions and aspirations of what a home entails, management styles, and design (Canada Mortgage and Housing Corporation, 1999; Memmott, 2003; 
Royal Commission on Aboriginal Peoples, 1996; Waldegrave et al, 2006). This is consistent with a growing body of evidence from a variety of policy fields which shows better outcomes when designed and delivered by Indigenous peoples (eg, Durie et al, 2002; Minore and Katt, 2007). As one group of scholars has recently argued in Canada, Aboriginal quality of life can be improved only on Aboriginal peoples' own terms and not prepackaged Eurocentric terms (Salée et al, 2006).

We accept the critique of self-government advanced by Alfred (2005) where it is seen as a state tool for redirecting the pursuit of fundamental individual, community, and national Indigenous self-determination into the networks of contemporary (colonial) social structures and relationships of power that maintain authority within the Settler state, its statutes and cultural norms. We proceed in this paper from the viewpoint that, notwithstanding this overarching critique of self-government, steps toward a more Indigenous-inclusive citizenship in urban areas can be achieved, if only marginally, by improving the experience of common social citizenship where state investment occurs.

In the delivery of services considered part of the common citizenship within a country which have the capacity to improve the urban quality of life of Indigenous peoples, selfgovernment in design and delivery can be an improvement. As we discussed above, however, contingencies remain. Arriving at self-government arrangements can also be a means of placating demands by Indigenous peoples for self-determining autonomy by creating less obvious but perhaps no less pernicious forms of 'state-determination', transferring new responsibilities for administration without jurisdiction and resources. In this paper, we examine the extent to which advances in self-government represent steps toward a more Indigenous-inclusive citizenship.

\section{Methods}

Documentary sources form the empirical basis for our paper and comprise archived and contemporary material. Collections at the Canadian Housing Information Centre at Canada Mortgage and Housing Corporation in Ottawa, Te Puni Kōkiri/Ministry of Māori Development library in Wellington, and the Australian Institute of Aboriginal and Torres Strait Islander Studies library in Canberra provided most of the material required. Credibility of the data sources was determined according to the authority of the author and the type or purpose of the publication (Robson, 1993). Using a variety of sources emanating from different sectors and positions in society served as a means of triangulation (Bradshaw and Stratford, 2000).

The historical accuracy of how policy trends in New Zealand and Australia are represented was checked with a prominent scholar of Indigenous housing in each country. The accuracy of the Canadian policy trends was reviewed by an official at Canada Mortgage and Housing Corporation and a member of the National Aboriginal Housing Association. In addition, having two researchers working on the project enhanced the credibility and dependability of analysis through continuous peer debriefing.

\section{Creating Indigenous-inclusive urban social housing policy in Canada}

In 1969 a federal government task force on housing and urban development, led by Paul Hellyer, proposed a number of important amendments to the National Housing Act, which over the following four years ushered in a series of new social housing programmes. At the same time, in 1969, a controversial federal government White Paper on Indian policy was tabled which proposed the termination of group rights for Aboriginal peoples as the best path toward improving their standing as full and equal citizens in Canadian society. Harold Cardinal, then president of the Indian Association of Alberta, wrote The Unjust Society (1969) and the 'Red Paper' (Indian Chiefs of 
Alberta, 1970, formally titled Citizens Plus) which mobilised Aboriginal peoples across Canada against the government's White Paper. Central to Cardinal's argument was that, in the absence of Aboriginal group rights, rather than become 'equal citizens', the position of Aboriginal peoples in Canada would deteriorate under a 'myth of equal opportunity and charity' (Cardinal, 1969). He proposed instead that Indigenous-inclusive citizenship be fostered where services and supports linked to common Canadian citizenship goals (eg, health, education) would be created and delivered by Aboriginal institutions with the support of the federal government in order to strengthen the foundations of Aboriginal society. This debate and mobilisation in 1969-70 led the federal government to abandon its White Paper and opened up a new era in the expansion of Aboriginal rights. The debate that occurred through the White and Red Papers is the earliest example (in recent decades) of the universal versus Indigenous-inclusive citizenship debate, or 'one size fits all' versus 'self-determination and living together differently' (Maaka and Fleras, 2005).

Kinew Housing was incorporated in 1970 as an independent nonprofit corporation, born from a housing working group at the Indian and Métis Friendship Centre in Winnipeg. Friendship Centres emerged in Canadian cities starting in the 1950s (but really took off in the $1960-70$ s) to provide a place for service referrals; advocacy; and social, cultural, and recreational programmes for urban Aboriginal peoples. Kinew was the first urban native housing corporation in Canada. Incorporation as a communitybased organisation was seen as "a step towards self-government and self-determination" (McNiven, 1971, page 5). Kinew Housing acquired inner city homes and renovated them for social housing. It was the progenitor of what would become a nation-wide urban native housing programme, generating over 100 nonprofit housing corporations delivering roughly 11000 units of (urban native) housing across Canada.

From its beginning, Kinew Housing was determined to provide 'soft services' in conjunction with physical housing infrastructure. These included counselling services for tenants in order to help them adapt to the urban environment, and for the labour force, many of whom were moving to the city for the first time from reserves and rural communities (Henderson, 1971). When an attempt to secure funding from the Canada Mortgage and Housing Corporation (CMHC) to employ a tenant counsellor as part of its general operations was unsuccessful in 1971, this was seen as a serious setback to achieving its corporate objectives. The inability at that time to implement the soft services - which up until the present time have been such a central component of the urban native housing programme - was an early hurdle to building Indigenousinclusive citizenship in a burgeoning social housing sector aimed at strengthening common social citizenship in Canada.

Additional funding was given on a discretionary basis by officials at CMHC responsible for urban native housing because the urban native units were generally older homes and were scattered around different areas of the city, following a pepper potting policy. This led to higher portfolio management costs than other social housing (Lipman, 1986). The Executive Committee of the CMHC called for an internal study to evaluate the operations of urban native housing projects in 1974. A submission to institute a continuing (as opposed to ad hoc) urban native housing programme was drafted by CMHC staff, with input from urban native housing organisations and advocates, and submitted to CMHC management. The CMHC management did not approve the submission, however, saying that it would amount to discrimination to do so, given that there were already general social housing programmes in place to serve the 'urban poor'.

At this key point in the history of what would eventually become a differentiated Urban Native Housing Program was a setback where the rationale of universal citizenship was used to decline a proposal designed to implement a programme that would 
have better suited the aspirations of urban Aboriginal communities. The official programme approval would not come for another seven years. In spite of this lack of formal recognition, however, significant progress was made toward improving the de facto urban native housing programme that had already emerged. An increase in funding for administration and maintenance was granted and funding for tenantcounselling costs was approved-two examples of how initiatives taken by local Aboriginal actors influenced change to the standardised operating parameters under the National Housing Act and began transforming the provision of social housing to Aboriginal households in a way that advanced the achievement of common social citizenship in urban areas.

In a tangible way the urban Aboriginal community was making changes at the margins of social housing policy, determining its own path in the sector, and taking steps toward Indigenous-inclusive citizenship. This began with the identification of housing as a priority at the Friendship Centre, followed by the incorporation of Kinew Housing - and then other organisations across the country-as a vehicle for operations, to affecting change to standardised federal social housing parameters in order to better meet the needs and aspirations of Aboriginal households. In 1981, after several years of further pressure from urban Aboriginal communities, the federal Cabinet approved an official Urban Native Housing Program (UNHP) and provided a 'deeper subsidy' to bring rents down to $25 \%$ of tenant income, alleviating the disproportionate housing hardship faced by Aboriginal people in cities.

The urban programme was the last of the suite of three Aboriginal housing programmes to be developed, reflecting common views of where priorities for the support of Indigeneity ought to be placed. First priority was reserve-based and rural Aboriginal communities. The on-reserve and rural and native housing programmes were started in the mid-1970s. In 1981 the UNHP was finally passed, even though during the 1970 s discretionary spending by CMHC officials who were advocates of urban Aboriginal housing was occurring if unofficially. This priority placement for Indigeneity outside of urban areas was assisted by the growth of new First Nations and Métis political organisations, particularly in the 1970s, which focused on core constituencies that were rural and reserve based, something evident in the lack of direct support from these organisations to Kinew Housing when it was getting started (McNiven, 1971).

The federal government discontinued the construction of new units under most of its social housing programmes after 1993, including the UNHP. It was not until 2001 that a very modest new investment in social housing occurred, under what was called the Affordable Housing Initiative, where a set of priority areas for new units were determined in consultation with each province and territory. In those bilateral negotiations the federal government did not undertake to secure a prioritisation for Aboriginal housing that would have, in effect, filled the policy space created and subsequently vacated by the discontinued UNHP. In fall 2006 new investment in the urban Aboriginal housing sector occurred under the Off-reserve Aboriginal Housing Trust. Each province and territory has negotiated a framework with the federal government in order to implement the new programme. It is in effect providing a lifeline for urban native housing corporations developed prior to 1993. In several provinces urban native housing corporations, or their provincial umbrella organisation, are active or primary partners in determining the priorities for resource distribution under the Off-reserve Aboriginal Housing Trust, picking up the thread of Indigenous-inclusive citizenship left over a decade before. They are also often the ones awarded the resources from the Trust either to conduct maintenance to their existing UNHP stock or to build or acquire new units. 


\section{Getting to Māori housing in urban areas-universal or Indigenous-inclusive?}

New Zealand launched its social housing sector earlier than either Canada or Australia: both its state housing programme and Māori housing scheme began in the 1930s. In 1934 a Māori Member of Parliament, Sir Apirana Ngata, Minister of Native Affairs, proposed a housing programme for Māori to complement both the mainstream state housing programme, which centred almost exclusively on urban centres, and the Māori settlement schemes, which aimed to establish Māori households 'on the land' and develop self-sustaining communities and rural lifestyles (Butterworth, 1990; Krivan, 1990).

The Native Housing Act (1935) provided the Board of Māori Affairs with the authority to provide loans to Māori households for the erection, repair, or improvement of housing and associated infrastructure (eg, water supply, sanitation, out-buildings). The rural focus of the Native Housing Act reflected both the location of most Māori households at the time and the predominant public view of the place where Māori households were best suited to live: namely, outside of towns and cities. It also disrupted cultural norms with respect to how Māori communities developed and housed people. For example, to qualify under the Māori housing scheme, a household had to possess individual title to a parcel of land, further motivating the disaggregation of community-held land. The requirement for individual title also contributed to the spatial separation of houses (Sissons, 2005). The Māori housing scheme was seen by government as a separate and exceptional programme to the mainstream state housing programme and, indeed, Māori would not be allowed to access state housing until the late 1940s because their place was perceived to be in rural areas and they were not seen to be fit in lifestyle or aspirations to settle amongst the working non-Māori family households going into suburban state housing (Ferguson, 1994; Krivan, 1990; Schrader, 2005).

Following World War II a larger number of Māori began to move to the country's urban centres, despite the continued focus of New Zealand government policy on maintaining Māori in the rural environment. The urbanisation trend among Māori was difficult to ignore and Māori parliamentarians in particular would not let it go unacknowledged. Since the beginning of the Māori housing scheme, Māori had argued that they also had a right to access state housing as regular working New Zealanders in housing need. In other words, they wanted access to common social citizenship. Their access to mainstream state housing was resisted by the State Advances Corporation (central government housing body) but was inevitable with the increasing urbanisation rates and disproportionate housing hardship compared with Pākehā.

In 1948 the Under-Secretary for the Department of Māori Affairs, T T Ropiha, proposed that a Māori Pool of state housing be set up around the country, with Māori allocation committees to select tenants in areas where the population size warranted, and by other 'civilian committees' in smaller urban centres. State Advances Corporation agreed with the proposal but on the basis that Māori be interspersed, 'pepperpotted' among non-Māori households in suburbs so that they too would adopt the nuclear family lifestyle and work habits (Ferguson, 1994; Krivan, 1990; Schrader, 2005). Despite the continued migration of large numbers of Māori to the country's urban centres, government policy throughout the 1950s and early 1960s was still generally predicated on the creation of Māori farms (Barcham, 2004).

The 1950s and 1960s were a time of increasing Māori access to mainstream state housing. The Māori Pool system was discontinued in the 1950s and access to mainstream state housing opened up. While ownership continued to be an alternative, particularly through the Māori housing scheme which was extended into urban areas in the 1950s, rental remained the most prevalent tenure among urban Māori. 
In 1960 the acting Secretary of Māori Affairs, Jack Hunn, published his review of the Department of Māori Affairs and social-welfare institutions aimed at assisting Māori people (Hunn, 1960). In his view, the best way to significantly improve the position of Māori was through 'integration' (ie, assimilation) with mainstream society-much like the Canadian federal government's White Paper on Indian policy would propose there in 1969. Interestingly, there were references to Māori social policy postHunn in the (Canadian) Prime Minister's justification of the White Paper to Aboriginal leaders (Trudeau, 1970). Hunn saw the encouragement of urbanisation and associated policy incentives as central to the integration project - the creation of universal citizenship among Māori and Pākehā. The approach advocated by Hunn and throughout the history of state housing initiatives in urban areas was based on universal citizenship, that 'one size should fit all'. In spite of a couple of special features granted by central government, such as Māori allocation committees for units in the Māori Pool of state housing, the intent was to ease the transition of urban Māori to the Pākehā lifestyle.

The Māori Pool of state housing had the potential to allocate state housing to Māori, conceivably (although not done) built to a size and layout consistent with cultural traditions. But, in practice, the delivery of units was small compared with need and the initiative was short-lived. The Māori Pool, as it eventuated, represented a step in a process from an explicit exclusion of Māori from common social citizenship in state housing (from 1930s until the late-1940s) to the provision of Pool units to Māori pepperpotted in the suburbs and managed by the Department of Māori Affairs, to finally opening up Māori access to mainstream, mostly urban, state housing from the late 1960s onward - in some part due to the universalising rationale of the Hunn Report. Between 1935 and 1967, an estimated 23000 permanent private dwellings were built for Māori between the Māori housing scheme and the Māori Pool of state rental housing (Krivan, 1990).

The 1970s would see a shift back to a predominantly rural focus for the Māori housing scheme. In the 1970s Māori households were gaining greater access to state rental housing in urban areas, which to politicians was an indication that a separateIndigenous-inclusive-Māori housing policy was unnecessary (Ferguson, 1994). At the same time, cultural difference between Māori and Pākehā society was beginning to gain some currency during the 1970s. This was prompted largely by the Treaty of Waitangi Act in 1975, which established the Waitangi Tribunal to hear contemporary grievances related to breaches of the 1840 Treaty, and by a 'land march' and protests in urban areas for Māori rights, led by the first President of the Māori Women's Welfare League (Sissons, 2005). Similar to the urban starting point for the Aboriginal land rights march in 1972, in Redfern, Sydney, Australia, the urban scale was a strategic point of Māori symbolic resistance to the universalising discourse of common New Zealand citizenship at that time. The Treaty of Waitangi Act and land march were key turning points in a Māori socioeconomic and cultural renaissance in the last quarter of the 20th century, as well as a conduit through which resources would flow back to Māori. Issues of self-determination, sovereignty, and the terms of partnership between Māori and Pākehā society were at the centre of social debates. This renewed focus on the Treaty of Waitangi and the rights and aspirations associated with it would play a role in rekindling calls for Indigenous-inclusive citizenship in the form of Māori housing initiatives in the 1980s.

A report on Māori housing was delivered by $\mathbf{J}$ Cornwall for the State Services Commission in 1982. The 'Cornwall Report' argued that there was little evidence of 'special Māori housing needs', beyond the needs experienced by Pākehā of similar socioeconomic status, except where multiply owned Māori land was concerned (Cornwall, 1982). This was opposed by the New Zealand Māori Council, which commissioned 
a report by Professor Whatarangi Winiata. Winiata argued that a special housing programme for Māori was needed on the basis of (1) cultural difference, (2) lower average socioeconomic status of Māori, and (3) overt racism in the housing market (Winiata, 1983). These bases parallel those articulated in Canada to advance the need for the UNHP. A report to the Board of Māori Affairs by Edward Douglas affirmed some of Winiata's main findings and argued for Indigenous-inclusive citizenship, with a 'Māori solution' to address housing disparity, rather than a Pākehā directed 'needbased' solution (Douglas, 1986). Douglas took direct issue with the monocultural thinking that permeated Cornwall's recommendations to government:

"Cornwall's findings reflected the monocultural thinking of the Housing Corporation and its unwillingness to recognize that their ethnicity was of great validity to members of minority cultures. Together, these policies have resulted in institutionalized racism" (1986, page 6).

Decades of policy which denied notions of Indigenous-inclusive citizenship based on self-determination or self-government in social welfare policy fields, and focused instead on an elusive universal citizenship, was being challenged in the 1980s with some consistency. The message was not only that there was higher need, but that there were also different approaches to be explored which would address better the aspirations among Māori. The philosophy of the Housing Corporation remained, however: not to draw distinctions in the creation of housing policies based on ethnicity or 'race', and to provide universal assistance to modest-income earners, a similar philosophy to that held by the CMHC management in response to the first application to formally institute the UNHP. One of the problems with universal approaches - and the central problem with imagining universal citizenship - is that they are designed on the assumption that European cultural norms permeating the bureaucracy, operating procedures, unit design, and delivery mechanisms are neutral and affect all cultural groups equally. The recommendations from Winiata and Douglas for a dedicated Māori housing initiative - that is, the setting aside of a portion of housing resource allocation for the delivery of Māori housing programming — alongside the mainstream state housing programme was never acted upon.

The Māori housing scheme was wound down in the early 1990s with a restructuring of Māori Affairs by central government. The focus from the 1990s to today has been almost exclusively on Māori housing in rural communities self-managed by iwi housing offices. Housing programmes have been pitched at 'rural' households, rather than as Māori housing initiatives. Yet, if you ask housing officials, they will explain that these programmes are oriented toward rural Māori communities although the official policy rationale of 'rural' instead of 'Māori' is the more acceptable political terminology.

\section{Creating and dismantling Indigenous-inclusive Australian housing policy}

A referendum on Constitutional amendment in 1967 opened up Aboriginal affairs to greater direct involvement by the Commonwealth government. It removed two exclusionary references to Aboriginal people and gave the Commonwealth power to make laws directly applicable to Aboriginal peoples. Aboriginal citizenship by assimilation would be replaced over a period of years following the referendum with ideas about protecting and enhancing Aboriginal culture, building a more Indigenous-inclusive Australian citizenship. Resurgence in Aboriginal identity and right-claims was also visible in the 1968-71 Gove Land Rights case, where the Yolngu people of Yirrkala mounted a legal challenge based on traditional occupancy against a bauxite-mining company that had secured a twelve-year lease on their lands. They claimed sovereign rights and native title over the land, but lost their case in court. In spite of the loss, the ruling was a catalyst for further legal and political challenges by Aboriginal society 
until the law on native title was finally overturned in the Mabo case in 1992. This ruling by the High Court of Australia made the declaration of terra nullius, that had been effective since the start of British colonisation in the late 1700s, irrelevant, and recognised a type of native title in property law, which has been extrapolated from there to form a basis for other right-claims based on prior occupancy in self-determining Indigenous societies.

A new set of housing interventions accompanied the increased Commonwealth presence in Aboriginal affairs. In 1968-69 the Commonwealth began to provide grants to state governments for the provision of public rental housing earmarked specifically for Aboriginal households (Sanders, 1993). Of this funding $40 \%$ was to be used by the states in their urban areas. This programme continues today, although its administration has shifted over the past decades through different Commonwealth departments. In 1979 it became the Aboriginal Rental Housing Program.

Aboriginal housing programmes followed a policy of pepperpotting in urban centres, like in both New Zealand and Canada. By the early 1970s up to a third of Aboriginal housing was being provided in urban centres (Long, 2000). This varied by state and territory with almost no funding, for example, going to urban Aboriginal housing in Queensland. While the issue of urban Aboriginal housing was not being ignored by governments, most funding and attention was still being directed to rural and remote regions, away from the majority of the Aboriginal population and in keeping with mainstream ideas of where authentic Indigenous communities ought to be located.

Following closely after the changes brought about by the 1967 referendum, two important events occurred in 1972. Hundreds of Aboriginal demonstrators "met at Redfern Park to launch a national land-rights march that would attract nationwide media coverage" (Anderson, 1993, page 319). Also that year the Labour government of Prime Minister Gough Whitlam was elected, which brought a significant change to Aboriginal affairs. Adopting a mandate to advance 'self-determination' for Aboriginal Australians, a number of policy changes were made by the new government. Of the Commonwealth Aboriginal Affairs budget in 1973, 30\% was set aside for a 'massive housing programme' (Commonwealth of Australia, 1991; Long, 2000).

The most significant new Aboriginal housing programme instituted by the Whitlam government, in 1972-73, was the Aboriginal housing associations grant programme (Long, 2000; Sanders, 1993). This programme provided resources for Aboriginal communities to develop and manage social rental housing. It was a grant to purchase land and housing with freehold title, permitting the housing associations considerable flexibility in determining housing type and location, tenancy, and property management, and the setting of rents. The state grants for Aboriginal public housing-morphed in 1979 into the Aboriginal Rental Housing Program - remained a cornerstone of the Aboriginal housing investment by Commonwealth (and state) government. It addressed a significant need, although these were simply earmarked public housing units with no regard to cultural difference in how Aboriginal urban communities might themselves have wished to design and deliver housing. Much like the Māori Pool in New Zealand, the Aboriginal Rental Housing Program was a slight modification to universal citizenship. The Aboriginal housing associations grant programme, on the other hand, was a tool for advancing self-determination in a limited sense, and transferring assets to Aboriginal communities. It was a modest step toward implementing Indigenous-inclusive citizenship.

The Aboriginal Housing Company in Redfern, Sydney, is one of the first examples of an organisation getting its start under this programme. Yet the activism of the Redfern Aboriginal community also had a significant impact on generating the 
mandate of the Whitlam government in Aboriginal affairs. By the early 1970s the availability of adequate and affordable housing was limited in Redfern and the surrounding inner-city areas. The Aboriginal community had grown to over 10000 , discrimination by landlords had increased, and the older inner suburban housing stock was being replaced with higher market units (Pitts, 2001). A series of events transpired, which we will not detail here (but see Anderson, 1993; Pitts, 2001), that led to the formation of a community-based Aboriginal Housing Committee, which included an Aboriginal law student, Bob Bellear, and his wife Kaye (a nurse), and others, including local priests. The Aboriginal Housing Committee and local allies, including a homebuilders' labour union, used their early base in two renovated housing units to lobby Whitlam's incoming government. Their efforts were well received and support through the housing association grants programme led the Aboriginal Housing Company in 1973 to become a flagship for implementing some self-determining autonomy in an urban Aboriginal policy sector (although note also that bureaucratic tools for ensuring accountability or withholding operating funds were levers variously used to direct the affairs of the Aboriginal Housing Company).

The housing association grants programme persisted for decades, although its administration transferred through different Commonwealth bodies (including the Aboriginal and Torres Strait Islander Commission) a couple of times and blended with a community infrastructure programme into the Community Housing and Infrastructure Program (CHIP). It is important to note that the majority of Aboriginal community housing associations developed under this programme were in rural and remote areas, where Aboriginal state public housing could not easily reach.

Building on the developments of the 1970s, the most significant Commonwealth housing programmes for Aboriginal Australians in the 1980s were (1) the provision of rental housing for Aboriginal tenants through earmarked transfers to state housing authorities; and, (2) the provision of rental housing through Aboriginal community housing associations. An important change in Aboriginal affairs occurred in 1990 when the Aboriginal and Torres Strait Islander Commission (ATSIC) was established. ATSIC operated as the highest representative body for Indigenous Australians, but also took over many of the functions of Commonwealth agencies. Nominally, it was to embody the notion of Indigenous-inclusive citizenship in Australian society. In practice, it was often only a self-management body across many policy fields, including housing, allowing the state to cushion itself from direct culpability for failures among Aboriginal communities in common citizenship sectors.

From the 1990s onward, most of the CHIP budget was spent on housing in rural and remote areas, maintaining the focus on these areas as the authentic home-places for Indigenous peoples. In 2001 there were 616 Indigenous community housing organisations (ICHOs) across Australia, amounting to 21287 dwelling units (Trewin, 2002). Of these, 267 housing organisations were in urban areas, totalling 4885 dwellings. The remaining majority, 349 organisations, managed 16402 dwellings in rural and remote communities. ATSIC was disbanded in 2004 and its closure saw Aboriginal programmes distributed among a variety of mainstream Commonwealth agencies.

The continuing poor housing conditions among Aboriginal Australians brought government housing ministers from across Australia together in 2001 to endorse a new national housing policy framework called Building a Better Future: Indigenous Housing to 2010 (BBF). The BBF framework changed direction after its mid-term review, from its focus on self-management to facilitating the incorporation of Aboriginal housing programmes into mainstream state public housing systems for increased efficiency. The BBF also shifted Commonwealth Aboriginal housing investments 
exclusively to rural and remote areas, leaving the urban areas for state governments to deal with through their mainstream state housing allocations.

The shift in Australian state housing toward pooling resources to take advantage of economies of scale (Commonwealth of Australia, 2001) has been occurring for several years now. The efficiency and effectiveness of the ICHOs operating under the CHIP (recall CHIP is the modern version of the housing association grants programme) came under close scrutiny with a report, commissioned by the Commonwealth government, that ultimately recommended the program be 'abolished' (PricewaterhouseCoopers, 2007). That recommendation was adopted, and from 2008-09 the CHIP is being replaced by the new Australian Remote Indigenous Accommodation programme (ARIA). The ARIA funds will be spent on new housing or rehabilitating existing CHIP units, provided that ownership is transferred from the ICHO to state or territorial housing authorities, or made available for purchase by an Aboriginal household. The programme is designed to phase out holdings of ICHOs and to bring Indigenous housing firmly under control of mainstream housing authorities.

\section{Indigenous-inclusive citizenship and social housing in comparative perspective}

Urban Indigenous communities in all three countries have to varying degrees had to work counter to a common public perception that Indigenous peoples belong in rural, remote, and reserve communities (Anderson, 2000; Barcham, 2000; Morgan, 2006; Peters, 1996). When urbanisation became too great a trend to ignore, notions of universal citizenship (Maaka and Fleras, 2005) prevailed in urban centres with regard to housing policy, with some exceptions.

The Urban Native Housing Program in Canada, born out of activism from Aboriginal community advocates starting at the Friendship Centre in Winnipeg, marked a significant measure of Indigenous-inclusive citizenship within the general development of a common national social housing system. In the early years, there were both pushes forward and pushes back from senior federal bureaucrats, either bolstering specific programme elements for urban native organisations, or noting that there were already programmes for the 'urban poor'. But persistence paid off, and the UNHP flourished for some time. While the Canadian social housing sector in general-like state housing in other Western countries-is in significant decline (Darcy, 1999; Thorns, 2000; Wolfe, 1998), urban Aboriginal housing is still regarded as a distinctive piece of the sector in new state housing initiatives. Self-government is still occurring in meaningful ways which lead to variants on social housing models that are culturally appropriate and which improve programme outcomes (Walker, 2008).

In Australia, Aboriginal community activism in Redfern, Sydney, at around the same time as activism in urban Canada, contributed to, and benefitted from, the Commonwealth government's housing association grants programme-later embedded in the Community Housing and Infrastructure Program. This programme led to the development of a set of urban Indigenous community housing organisations across Australia. In many ways this resembles the Indigenous-inclusive citizenship developed in Canadian social housing, except that it was not a discrete urban programme, and indeed, most ICHOs are in rural and remote Aboriginal communities, where Australians have continued to imagine Indigenous peoples.

Only a couple of years after the ATSIC was dismantled the Indigenous housing sector in Australia is being aggressively wound down both by Commonwealth and by state governments, unlike in Canada. Increasingly, urban Indigenous housing needs will be met strictly through state housing authorities. The contingent nature of selfdetermining autonomy in the Australian Indigenous housing sector becomes very clear with the recent transformations. The ATSIC was simply wound down by the Settler 
government, and housing organisations which started as examples of 'self-determination' in urban service delivery are just as summarily being terminated.

The precarious nature of even a seemingly quite well entrenched set of self-governing Indigenous institutions takes us back to Alfred's (2005) principled rejection of the notion of self-government as just another form of state control. In very rapid and palpable ways, decades of work in the Indigenous community housing sector is being unravelled. The Australian Aboriginal Rental Housing Program, on the other hand, is being continued and is prominent in urban centres. It is not a program that moves toward Indigenous-inclusive citizenship, however, given that it is simply an earmarked portion of public housing units for Indigenous households, in response to their disproportionate need.

New Zealand has never had an urban Indigenous housing programme that advances Indigenous-inclusive citizenship. The Māori pool of state housing acted for about a decade as a transitory measure between full exclusion of Māori from universal citizenship in state housing to full eligibility, although with poorer outcomes than among non-Māori state housing tenants (Douglas, 1986). The Māori housing scheme, an assisted ownership programme, was not focused on urban areas except for during a very brief period, and was embedded in government objectives to provide rural community development among Māori. In effect, Indigenous-inclusive citizenship in the urban social housing sector was never achieved although, as in the other two countries, activism in the 1970s prompted a serious debate among Māori and state officials about a culturally appropriate Māori housing initiative. The terms of universal citizenship held fast in New Zealand. The New Zealand Housing Strategy adopted in 2005 has maintained this position (Housing New Zealand Corporation, 2005).

\section{Conclusion}

Although social housing is just one urban policy field, it is significant to the decolonisation of our cities (Sandercock, 2003) and the strengthening of urban Indigeneity. Indigenous peoples have been and continue to be the most poorly housed group in Canadian, New Zealand, and Australian cities (Australian Bureau of Statistics, 2002; Statistics Canada, 2008; Statistics New Zealand, 2002). The Canadian UNHP has been significant in the development of urban Indigenous communities. It has affected many people's lives and some of those stories have been shared in statements to the Royal Commission on Aboriginal Peoples (1996).

Households have been able to pursue education, employment, and other communityrelated aspirations once situated in culturally appropriate, affordable urban housing. They have also been able to build other Indigenous community institutions in the city, addressing educational, recreational, spiritual, political, and economic development. A well developed set of urban Indigenous institutions is seen as fundamental to creating a sense of place and quality of life in urban areas for Indigenous peoples (Royal Commission on Aboriginal Peoples, 1996), and the housing organisations from the UNHP are among the oldest of urban institutions.

The strength of the relationship between Settler and Indigenous peoples in cities across all three countries will be negatively affected by movements away from Indigenous-inclusive citizenship in the social housing sector. At this time it appears that only Canada is practising a form of Indigenous-inclusive citizenship in the provision of this common field of social welfare. As the recent Australian experience of winding down Indigenous community housing organisations has shown, however, the terms of the relationship between the Settler state and Indigenous peoples can change very quickly. Moreover, the change can be initiated unilaterally by the Settler state. 
Scholars in all three countries should aim to move beyond the identification and lamentation of quantitative disparities between Indigenous and non-Indigenous populations on standard socioeconomic indicators. We need to advance our knowledge of how the place-based outcomes associated with exercising Indigenous-inclusive citizenship in different policy fields help to decolonise our cities and augment the quality of life for all peoples.

Acknowledgements. We thank the National Aboriginal Housing Association in Canada for articulating the need for a comparative study of this kind, and the Canada Mortgage and Housing Corporation for funding our work. For animating our policy research with helpful and enjoyable discussions we thank David Seymour, Charles Hill, Phil Deacon, Robin Kearns, Will Sanders, Col James, and the late George Devine. We owe three anonymous referees our sincere thanks for helping us to improve the calibre of the paper.

\section{References}

Alfred T, 1999 Peace, Power, Righteousness: An Indigenous Manifesto (Oxford University Press, Toronto)

Alfred T, 2005 Wasáse: Indigenous Pathways of Action and Freedom (Broadview Press, Peterborough, $\mathrm{ON}$ )

Andersen C, Denis C, 2003, "Urban natives and the nation: before and after the Royal Commission on Aboriginal Peoples" The Canadian Review of Sociology and Anthropology 40373 -390

Anderson K, 1993, "Place narratives and the origins of inner Sydney's aboriginal settlement, 1972 - 73" Journal of Historical Geography 19314 - 335

Anderson K, 2000, “'The beast within': race, humanity, and animality” Environment and Planning D $18301-320$

Australian Bureau of Statistics, 2002, "Aboriginal and Torres Strait Islander Australians: a statistical profile from the 1996 Census" Year Book Australia (Australian Bureau of Statistics, Canberra)

Barcham M, 1998, "The challenge of urban Māori: reconciling conceptions of indigeneity and social change" Asia Pacific Viewpoint 39303 - 314

Barcham M, 2000, "(De)Constructing the politics of indigeneity", in Political Theory and the Rights of Indigenous Peoples Eds D Ivison, P Patton, W Sanders (Cambridge University Press, Toronto) pp $137-151$

Barcham M, 2004, "The politics of Māori mobility", in Population Mobility and Indigenous Peoples in Australasia and North America Eds J Taylor, M Bell (Routledge, London) pp 163-183

Bradshaw M, Stratford E, 2000, "Qualitative research design and rigour", in Qualitative Research Methods in Human Geography Ed. I Hay (Oxford University Press, Toronto) pp 37-49

Butterworth G, 1990 Mãori Affairs Iwi Transition Agency, Wellington

Cairns A, 2000 Citizens Plus: Aboriginal Peoples and the Canadian State (UBC Press, Vancouver)

Canada Mortgage and Housing Corporation, 1999 Evaluation of the Urban Social Housing Programs Canada Mortgage and Housing Corporation, Ottawa

Cardinal H, 1969 The Unjust Society: The Tragedy of Canada's Indians (M G Hurtig, Edmonton)

Commonwealth of Australia, 1991 Royal Commission into Aboriginal Deaths in Custody (Government of Australia, Canberra)

Commonwealth of Australia, 2001, "We can do it! The needs of urban dwelling Aboriginal and Torres Strait Islander peoples", House of Representatives Standing Committee on Aboriginal and Torres Strait Islander Affairs, Canberra

Cornwall J P M, 1982 Mãori Housing Review: A Review of Māori Housing Activities-Changes in Housing Policies which could Better Meet Mãori Housing Needs (State Services Commission, Wellington)

Darcy M, 1999, "The discourse of 'community' and the reinvention of social housing policy in Australia" Urban Studies 3613 - 26

Douglas E M K, 1986 Fading Expectations: The Crisis in Māori Housing Board of Maōri Affairs, Wellington

Durie M H, 1998 Te Mana Te Käwanatanga: The Politics of Māori Self-determination (Oxford University Press, Toronto)

Durie M H, 2003 Ngā Kāhui Pou Launching Mãori Futures (Huia Publishers, Wellington)

Durie M, Fitzgerald E, Kingi T, McKinley S, Stevenson B, 2002 Māori Specific Outcomes and Indicators Te Puni Kōkiri/Ministry of Māori Development, Wellington

Ferguson G, 1994 Building the New Zealand Dream (Dunmore Press, Palmerston North) 
Fleras A, Spoonley P, 1999 Recalling Aotearoa: Indigenous Politics and Ethnic Relations in New Zealand (Oxford University Press, Toronto)

Green J, 1997, "Options for achieving Aboriginal self-determination" Policy Options 1811 - 15

Green J, 2005, "Self-determination, citizenship, and federalism as palimpsest", in Reconfiguring Aboriginal - State Relations. Canada: The State of the Federation, 2003 Ed. M Murphy (McGill - Queen's University Press, Montreal and Kingston)

Henderson D G, 1971 A Second Report on the 'Kinew Housing Incorporated' Experiment (Institute of Urban Studies, Winnipeg)

Housing New Zealand Corporation, 2005 Building the Future: The New Zealand Housing Strategy Housing New Zealand Corporation, Wellington

Howitt R, 2001, "Frontiers, borders, edges: liminal challenges to the hegemony of exclusion" Australian Geographical Studies $39233-245$

Hulchanski J D, 2002 Housing Policy for Tomorrow's Cities (Canadian Policy Research Networks, Ottawa)

Hunn J, 1960 Report on Department of Māori Affairs (Government Printer, Wellington)

Indian Chiefs of Alberta, 1970 Citizens Plus (Indian Association of Alberta, Edmonton)

Krivan M, 1990, "The Department of Māori Affairs Housing Program, 1935 to 1967", unpublished MA thesis, Department of History, Massey University, Palmerston North

Kymlicka W, 2001, "The new debate over minority rights", in Canadian Political Philosophy: Contemporary Reflections Eds R Beiner, W Norman (Oxford University Press, Toronto)

Lipman M, 1986, "Historical review of CMHC's urban Native housing activity", in Urban Native Housing in Canada Research and Working Paper No. 19, Eds M Lipman, C Brandt (Institute of Urban Studies, Winnipeg)

Long J, 2000, "The Commonwealth government and aboriginal housing 1968-81", in Settlement: A History of Australian Aboriginal Housing Ed. P Read (Aboriginal Studies Press, Canberra)

Maaka R, 1994, "The new tribe: conflicts and continuities in the social organisation of urban Māori” The Contemporary Pacific 6311 - 336

Maaka R, Fleras A, 2005 The Politics of Indigeneity: Challenging the State in Canada and Aotearoa New Zealand (University of Otago Press, Dunedin)

McNiven J D, 1971 An Evaluation of Kinew Housing Incorporated (Institute of Urban Studies, Winnipeg)

Maynard J, 2007 Fight for Liberty and Freedom: The Origins of Australian Aboriginal Activism (Aboriginal Studies Press, Canberra)

Memmott P (Ed.), 2003 Take2: Housing Design in Indigenous Australia The Royal Australian Institute of Architects, Red Hill

Mercer D, 2003, “'Citizen minus'?: Indigenous Australians and the citizenship question” Citizenship Studies $7421-445$

Minore B, Katt M, 2007 Aboriginal Health Care in Northern Ontario: Impacts of Self-determination and Culture (Institute for Research on Public Policy, Montreal)

Mochama A, 2001 Residential Mobility of the Urban Poor: A Study of Female-headed Single Parent Aboriginal Households in Winnipeg unpublished MCP thesis, Department of City Planning, University of Manitoba, Winnipeg

Morgan G, 2006 Unsettled Places: Aboriginal People and Urbanisation in New South Wales (Wakefield Press, Kent Town, South Australia)

Mulgan R, 1998, "Citizenship and legitimacy in post-colonial Australia”, in Citizenship and Indigenous Australians: Changing Conceptions and Possibilities Eds N Peterson, W Sanders (Cambridge University Press, Melbourne) pp 175-195

Peters E J, 1996, “'Urban' and 'Aboriginal': an impossible contradiction?”, in City Lives and City Forms: Critical Research and Canadian Urbanism Eds J Caulfield, L Peake (University of Toronto Press, Toronto) pp 47-62

Peterson N, Sanders W (Eds), 1998 Citizenship and Indigenous Australians: Changing Conceptions and Possibilities (Cambridge University Press, Toronto)

Pitts A, 2001 Community Social Plan: Pemulwuy Reconstruction Project Aboriginal Housing Company Ltd, Sydney

PricewaterhouseCoopers, 2007 Living in the Sunburnt Country -Indigenous Housing: Findings of the Review of the Community Housing and Infrastructure Program Department of Families, Community Services and Indigenous Affairs, Canberra

Read P (Ed.), 2000 Settlement: A History of Australian Indigenous Housing (Aboriginal Studies Press, Canberra) 
Robson C, 1993 Real World Research: A Resource for Social Scientists and Practitioner-Researchers (Blackwell, Toronto)

Royal Commission on Aboriginal Peoples, 1996, "Urban perspectives", in Report of the Royal Commission on Aboriginal Peoples 4 chapter 7, Minister of Supply and Services, Ottawa

Salée D, Newhouse D, Lévesque C, 2006 Quality of Life of Aboriginal People in Canada: An Analysis of Current Research (Institute for Research on Public Policy, Montreal)

Sandercock L, 2003 Cosmopolis II: Mongrel Cities in the 21st Century (Continuum, New York)

Sanders W, 1993, "Aboriginal housing", in Housing Australia Ed. C Paris (Macmillan, Melbourne)

Schrader B, 2005 We Call it Home: A History of State Housing in New Zealand (Reed, Auckland)

Sissons J, 2005 First Peoples: Indigenous Cultures and their Futures (Reaktion Books, London)

Skelton I, 2002, "Residential mobility of Aboriginal single mothers in Winnipeg: an exploratory study of chronic moving" Journal of Housing and the Built Environment 17127 - 144

Statistics Canada, 2008 Aboriginal Peoples in Canada in 2006: Inuit, Métis and First Nations, 2006 Census (Statistics Canada, Ottawa)

Statistics New Zealand, 2002, "Census snapshot: Māori” 2001 Census of Population and Dwellings (Statistics New Zealand, Wellington)

Thorns D C, 2000, "Housing policy in the 1990s: New Zealand a decade of change" Housing Studies $15129-138$

Trewin D, 2002 Housing and Infrastructure in Aboriginal and Torres Strait Islander Communities, Australia, 2001 (Australian Bureau of Statistics, Canberra)

Trudeau P E, 1970 Statement by the Prime Minister at a Meeting with the Indian Association of Alberta and the National Indian Brotherhood, Ottawa, 4 June (Prime Minister's Office, Ottawa)

Waldegrave C, King P, Walker T, Fitzgerald E, 2006 Māori Housing Experiences: Emerging Trends and Issues Centre for Housing Research, Aotearoa New Zealand and Te Puni Kōkiri, Wellington

Walker R, 2006, "Searching for Aboriginal/indigenous self-determination: urban citizenship in the Winnipeg low-cost-housing sector, Canada" Environment and Planning A 38 2345-2363

Walker R, 2008, Social Housing and the Role of Aboriginal Organizations in Canadian Cities (Institute for Research on Public Policy, Montreal)

Walker R, Moore J, Linklater M, forthcoming, "More than stakeholders, voices and tables: towards co-production of urban Aboriginal affairs policy in Manitoba", in Multi-level Governance and Aboriginal Public Policy in Canadian Municipalities Eds R Young, E Peters (McGill-Queen's University Press, Montreal and Kingston)

Winiata W, 1983 Māori Home Ownership New Zealand Māori Council, Wellington

Wolfe J M, 1998, "Canadian housing policy in the nineties" Housing Studies 13121 - 133

Wood P K, 2003, “Aboriginal/indigenous citizenship: an introduction” Citizenship Studies 7371 - 378 